\title{
Protein Separation in Functional Rice Grains Using Two-Dimensional Gel Electrophoresis
}

\author{
Soo Im Chung*, Sang Chul Lee**, and Mi Young Kang* ${ }^{\dagger}$ \\ *Department of Food Science and Nutrition, Kyungpook National University, Daegu 702-701, Korea \\ **Division of Plant Biosciences, Kyungpook National University, Daegu 702-701, Korea
}

\begin{abstract}
The proteins from functional rice cultivars (Nogwonchalbyeo, Giant embryonic, Arhyangchalbyeo, and Goamibyeo) and general white rice were extracted and separated using two-dimensional (2D) gel electrophoresis. A wide variation in the molecular weight $(\mathrm{MW})$ and $\mathrm{pH}$ range of the expressed proteins in rice samples were observed. The green-kerneled rice (Nogwonchalbyeo) exhibited proteins with $\mathrm{MW}$ of $9-57 \mathrm{kDa}$ and appeared at a $\mathrm{pH}$ range of 4-7. The Giant embryonic contained proteins with MW of 31-63 $\mathrm{kDa}$ and a $\mathrm{pH}$ range of 5-6. The aromatic glutinous rice (Arhyangchalbyeo) showed proteins with MW of 24-28 and $\mathrm{pH}$ of 5.8-6.8. The high-amylose rice (Goamibyeo) exhibited proteins with MW of 3-63 and $\mathrm{pH}$ of 5.2-5.6. The identified proteins uniquely found and highly expressed in each cultivar may have a significant role on rice functionality. The results illustrate that the 2D gel electrophoresis is a valuable method in the determination of the protein expression profiles in functional rice grains and may be useful in the identification of specific marker proteins associated with the functional property of rice.
\end{abstract}

Keywords : functional rice, gel electrophoresis, rice protein

Rice (Oryza sativa L.), one of the most important and widely grown cereal crops in the world, is the main staple food in various countries, particularly in Asia. With the increasing popularity and market demand for functional foods, rice breeders and agricultural scientists across the world have focused on the development of specialty rice varieties with functional properties. For the past years, several new lines of rice with enhanced nutritional quality have been produced such as golden rice, giant embryo rice, pigmented rice, and high-amylose rice. Establishing specific biomarkers for rice functionality could assist plant breeders in the development of rice grains with improved functional quality.

Proteomic analysis using two-dimensional polyacrylamide gel electrophoresis (2D-PAGE) coupled with mass spectrometry is a very useful and powerful technique for the identification and differentiation of expressed proteins in plant tissues (Gygi et al., 2000). The development of rice protein databases based on 2D-PAGE has enabled the identification of known proteins and facilitated the analysis of new proteins with respect to their physiological significance in rice (Komatsu et al., 1993, 2004). Proteomic analysis of rice has been mainly focused on the changes in protein expressions during rice growth and development under different environmental conditions (Komatsu et al., 2003). Studies on the protein profile of rice in relation to grain quality have been limited and there were no reports yet on the protein expression profile of rice grains with varying functional properties.

This study was carried out to examine and compare the protein profile of rice grains with different functional properties using 2D electrophoresis technique. The results of this study could serve as baseline information for rice breeders in the identification and analysis of proteins that contribute to the functional quality of rice.

\section{MATERIALS AND METHODS}

\section{Protein Extraction}

Five rice varieties were obtained from Rural Development Administration (Suwon, Korea). The proteins were extracted based on the method described of Cascardo et al. (2001) with some modifications. Briefly, the white rice grains (100 mg) were frozen and ground into fine powder using liquid nitrogen. The sample was mixed with $50 \mathrm{mM}$ Tris

\footnotetext{
${ }^{\dagger}$ Corresponding author: (Phone) +82-10-3820-9797 (E-mail) mykang@knu.ac.kr

$<$ Received 8 August, 2013; Accepted 30 October, 2013>
} 
$(1 \mathrm{~mL}, \mathrm{pH} 8.0)$ and $100 \mathrm{mM} \mathrm{NaCl}$ solution, incubated for $3 \mathrm{hr}$ at room temperature, and centrifuged (12000 rpm, 30 $\min , 4^{\circ} \mathrm{C}$ ). The supernatant was added with tricholoroacetic acid, incubated for over $12 \mathrm{hr}$ at $4{ }^{\circ} \mathrm{C}$, and centrifuged $\left(12000 \mathrm{rpm}, 30 \mathrm{~min}, 4^{\circ} \mathrm{C}\right)$. The pellet was washed twice with cold acetone and dried at $50^{\circ} \mathrm{C}$. The proteins were then solubilized in a lysis buffer consisting of $2 \mathrm{M}$ thiourea, $7 \mathrm{M}$ urea, 4\% (w/v) CHAPS, 0.2\% (w/v) DTT. The sample $(10 \mathrm{mg})$ was suspended in $250 \mu \mathrm{L}$ of lysis buffer, incubated $\left(37^{\circ} \mathrm{C}, 1 \mathrm{hr}\right)$ with continuous stirring, and centrifuged (15 min, $12000 \mathrm{rpm}$, room temperature). The supernatant served as the protein extract for analysis.

\section{Two-Dimensional Gel Electrophoresis}

The proteins were separated based on $\mathrm{pH}$ through isoelectric focusing (IEF) following the method of Komatsu et al. (1993). The IEF was performed horizontally with Ethan IPGphor Isoelectric focusing system (Amersham Biosciences, GE Healthcare, Buckinghamshire, UK) while the sodium dodecyl sulfate-polyacrylamide gel electrophoresis (SDSPAGE) was performed in a vertical slab gel unit (Hoffer Scientific Instruments, San Francisco, CA). The IEF was performed with a preformed immobilized $\mathrm{pH}$ gradient (IPG; pH gradient 3 to 10, GE Healthcare Biosciences, Buckinghamshire, UK). The isoelectric running conditions were as follows: $500 \mathrm{~V}$ for $1 \mathrm{hr}$ followed by $1000 \mathrm{~V}$ for 1 $\mathrm{hr}$ and finally $3000 \mathrm{~V}$ for $16 \mathrm{hr}$. The focused strips were equilibrated twice for $28 \mathrm{~min}$ in $2 \mathrm{~mL}$ equilibration buffer.

\section{Gel Staining}

The gels were immersed in fixative solution (methanol/ distilled water/acetic acid, 5/4/1) for $1 \mathrm{hr}$, followed by immersion on a staining solution (fixative solution with 0.5 g commasie blue) for a minimum of $3 \mathrm{hr}$ (Komatsu et al., 1993). After staining, gels were re-immersed in a fixative solution for $5 \mathrm{~min}$ and placed in a destaining solution (methanol/distilled water/acetic acid, 3/1/6) for $3 \mathrm{hr}$. The gels were immersed in distilled water and stored in refrigerator.

\section{Image Analysis}

The commasie blue stained gels were scanned using a UMAX PowerLook 2100XL (UMAX, Australia) and image files were exported to the PDQuest 2-D gel analysis software (Bio-Rad, CA). Spots that have high intensities $(>1000)$ and unique to each cultivar were cropped and the cropped spots were counted by an automatic spot detection. The image intensities of protein spots located at the same molecular weight and $\mathrm{pH}$ on different gels were compared with each other. The image analyzer automatically recognized the gel with the highest number of spots, which served as the reference image. The experiment was done in duplicate and the images were identical from each running for the same cultivar.

\section{In-Gel Digestion of Proteins}

Following the method of Rosenfeld et al. (1992), the protein spots of interest were excised from gels, minced with scalpel, washed with distilled water and de-stained with $50 \mathrm{mM}$ ammonium bicarbonate in acetonitrile. The gels were freeze-dried, trypsinized with $20 \mu \mathrm{L}$ trypsin solution $\left(10 \mathrm{ng} / \mathrm{ml}\right.$ in $\left.50 \mathrm{mM} \mathrm{NH} \mathrm{CO}_{3}\right)$, incubated (45 min on ice), and subjected to in-gel digestion $\left(18 \mathrm{hr}, 37^{\circ} \mathrm{C}\right.$ water bath). The gel mixture was centrifuged $(12,000 \mathrm{rpm}$ at $4^{\circ} \mathrm{C}$ ) and the gel pieces were re-suspended twice in 20 $\mu \mathrm{L}$ solution of $0.1 \%$ tri-fluoro acetic acid (TFA) in $60 \%$ ACN. The supernatant for each gel mixture was combined and freeze-dried for $1 \mathrm{hr}$, then suspended in of $0.1 \%$ TFA (7 $\mu \mathrm{L}$ ). The resulting solution was mixed with $1 \mu \mathrm{L}$ matrix solution (10 $\mathrm{mg}$ in $50 \% \mathrm{ACN}$ in $0.1 \% \mathrm{TFA}$ ) and spotted on the marker assisted laser desorption ionization (MALDI) plate and dried entirely in a clean bench. Washing of each spotted sample was done using $5 \%$ formic acid and distilled water.

\section{Marker Assisted Laser Desorption Ionization-Time of Flight (MALDI-TOF) Mass Spectrometry (MS)}

Measurements were performed on Voyager DE-STR MALDI-TOF mass spectrometer (Applied Biosystems, Forster City, CA) equipped with a reflectron (Vorm et al., 1994). The spectra were acquired in the delayed extraction, reflector mode, in an optimized condition $(20 \mathrm{kV}$ acceleration voltage, $200 \mathrm{~ns}$ delay time). The mass scale was internally calibrated with the trypsin autolytic products of known amino acid sequence: m/z 1296.685 (angiotensin), 1060.569 (bradykinin) and 1672.92 (neurotensin). 


\section{Protein Database Search}

The mass values of the analyzed peptides were used for database search via MS-fit (Protein Prospector, University of California, San Francisco, CA) and Mascot search engine, which uses the raw MS/MS data to search the NCBI and SwissProt protein database. Protein identification was considered accurate when the MS/MS results from three to four peptides identified the same protein.

\section{RESULTS AND DISCUSSION}

The 2D gel electrophoresis technique, in combination with mass spectrometry, has been widely used in the separation of complex protein mixtures and identification of protein spots. A recent investigation on rice protein showed that the 2D electrophoresis technique may possibly be useful in identifying marker proteins that could affect rice palatability (Chung et al., 2012). In the present study, the protein expression profile of rice cultivars with varying functionality was analyzed. The identities of the protein spots with high image intensities $(>1000)$ and unique to each rice sample are shown in Table 1. The Nogwonchalbyeo cultivar, a green-kerneled rice that has high chlorophyll content (Chu et al., 2004; Kang et al., 2008), showed four unique protein spots (Fig. 1A) identified as hypothetical proteins, protein disulfide isomerase, and Os05g0474600. The separated proteins appeared in $\mathrm{pH}$ range of 4-7 with mass weights of 9-57 kDa. The Giant embryonic cultivar, a rice that has a larger embryo size than normal, also exhibited four significant protein spots (Fig. 1B). The proteins, identified as hypothetical proteins, Os04g0404400, and Os10g0463800, had mass weights of 31-63 kDa with $\mathrm{pH}$ range of 5-6. The Arhyangchalbyeo cultivar, an aromatic glutinous rice, exhibited three unique protein spots that appeared in $\mathrm{pH}$ range of 5.8-6.8 with molecular mass of 24-28 kDa (Fig. 1C). Among the rice samples analyzed, the Goamibyeo cultivar, a high amylose rice (Song et al., 2008), showed the least number of unique

Table 1. Proteins expressed in functional rice grains.

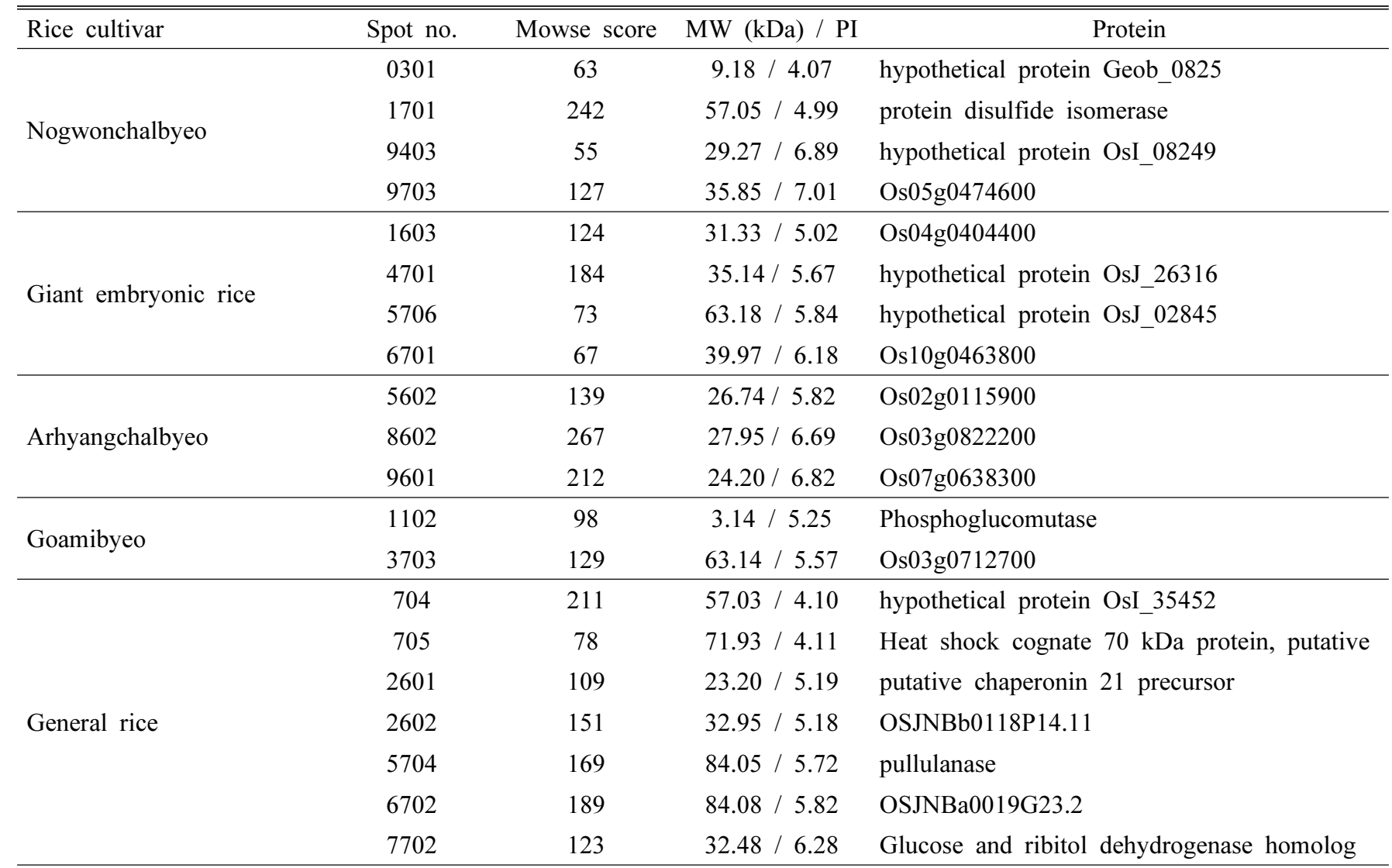




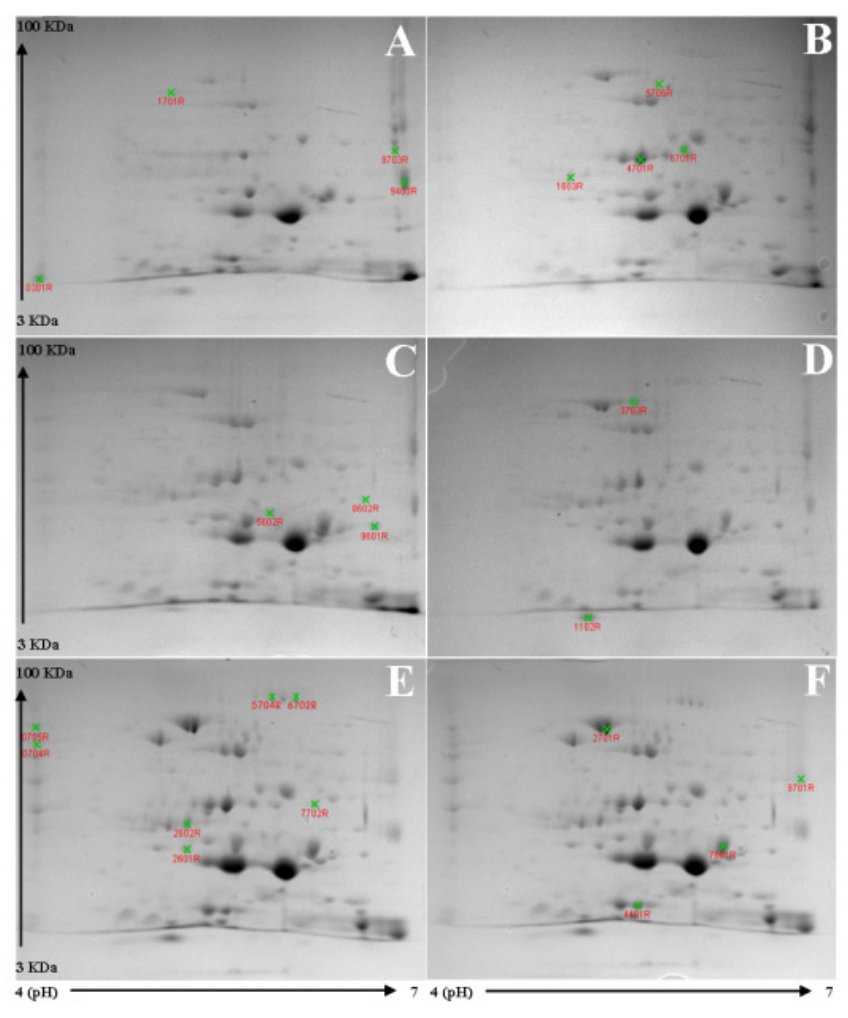

Fig. 1. Two-dimensional gel pattern of proteins from Nogwonchalbyeo (A), Giant embryonic (B), Arhyangchalbyeo (C), Goamibyeo (D), and general rice (E) cultivars, and common proteins from the five cultivars analyzed (F). Numbered spots refer to identified proteins (Tables 1 and 2).

Table 2. Common proteins expressed in all the rice samples.

\begin{tabular}{cccl}
\hline \hline Spot no. & Mowse score & MW (kDa) / PI & \multicolumn{1}{c}{ Protein } \\
\hline 2701 & 285 & $73.67 / 5.23$ & $\begin{array}{l}\text { endosperm lumenal } \\
\text { binding protein }\end{array}$ \\
4401 & 135 & $16.45 / 5.57$ & Os07g0213600 \\
7601 & 155 & $24.93 / 6.31$ & RAB24 protein \\
9701 & 92 & $44.65 / 6.89$ & hypothetical protein \\
& & & OsJ_26834 \\
\hline
\end{tabular}

protein spots (Fig. 1D). The separated proteins were identified as phosphoglucomutase and Os03g0712700 with mass weights of 3 and $63 \mathrm{kDa}$ and $\mathrm{pH}$ of 5.2 and 5.6, respectively. The general white rice cultivar exhibited the highest number of significant protein spots, with 7 unique spots that appeared in the $\mathrm{pH}$ range of 4-6 and had mass weights of 23-84 $\mathrm{kDa}$ (Fig. 1E). Among the proteins identified were heat shock cognate $70 \mathrm{kDa}$ protein, putative chaperonin 21 precursor, pullulanase, and glucose and ribitol dehydrogenase homolog. Since these proteins were found in the general white rice, they may have no considerable influence on rice functionality.

Using an image analyzer, the images obtained from all the rice samples were compared and the protein spots with high intensities $(>1000)$ and expressed in all samples were selected and identified. A representative image for these common protein spots and their identities are shown in Fig. 1F and Table 2, respectively. The presence of these four proteins (endosperm luminal binding, Os070213600, RAB24 protein, and hypothetical protein OsJ_26834) in all the rice samples suggests that they may not have a significant role on the functional quality of rice. On the other hand, the different proteins uniquely expressed among the four functional rice cultivars could possibly be associated with rice functionality. The separated proteins varied widely with respect to their molecular weights and $\mathrm{pH}$. However, the exact role of each identified protein on the functional properties of rice is still unknown and cannot be elucidated from the present study. This research showed for the first time that protein profiling of different functional rice cultivars is possible using $2 \mathrm{D}$ gel electrophoresis. The results could serve as a basis for future study on a more comprehensive and quantitative proteome analysis of rice in relation to functional quality.

In conclusion, the present study illustrate that the 2D gel electrophoresis technique is a powerful approach in analyzing the differences in the protein profile of various functional rice grains. The separation and characterization of rice proteins based on $\mathrm{pH}$ and molecular masses may be valuable in identifying marker proteins that contribute to the functional quality of rice. Further research is needed on the protein expression profile of other rice cultivars with different functional properties to better understand the role of proteins on rice functionality.

\section{ACKNOWLEDGMENTS}

This work was supported by a grant from the NextGeneration BioGreen 21 Program (Plant Molecular Breeding Center No. PJ008176), Rural Development Administration, Republic of Korea and Kyungpook National University Research Fund, 2013. 


\section{REFERENCES}

Cascardo, J. C., R. A. Buzeli, R. S. Almeida, W. C. Ontoni, and E. P. Fontes. 2001. Differential expression of the soybean BiP gene family. Plant Sci. 160 : 273-281.

Chu, S. H., H. H. Lee, S. N. Ryu, and H. J. Koh. 2004. Grain characteristics and inheritance of green-kerneled rice (Oryza sativa L.). Kor. J. Breed. 36 : 222-228.

Chung, S. I., C. W. Rico, S. C. Lee, and M. Y. Kang. 2012. Separation of proteins from rice grains with different eating qualities by two-dimensional gel electrophoresis. Agron. J. $104: 49-53$.

Gygi, S. P., G. L. Corthals, Y. Zhang, Y. Rochon, and R. Aebersold. 2000. Evaluation of two-dimensional gel electrophoresis-based proteome analysis technology. Proc. Natl. Acad. Sci. USA 97 : 9390-9395.

Kang, S. Y., I. C. Shin, D. S. Kim, G. J. Lee, J. B. Kim, D. Y. Lee, S. Y. Lee, and D. J. Lee. 2008. A new greenkerneled glutinous rice mutant variety, "Nogwonchalbyeo" developed by gamma ray irradiation. Kor. J. Breed. Sci. 40 : 303-307.

Komatsu, S., H. Kajiwara, and H. Hirano. 1993. A rice protein library : a data-file of rice proteins separated by two-dimensional electrophoresis. Theor. Appl. Genet. 86 : 936-942.

Komatsu, S., H. Konishi, S. Shen, and G. Yang. 2003. Rice proteomics: a step toward functional analysis of the rice genome. Mol. Cell. Proteomics 2 : 2-10.

Komatsu, S., K. Kojima, K. Suzuki, K. Ozaki, and K. Higo. 2004. Rice proteome database based on two-dimensional polyacrylamide gel electrophoresis : its status in 2003. Nucleic Acid Res. 32 : D388-D392.

Rosenfeld, J., J. Capdevielle, J. C. Guillemot, and P. Ferrara. 1992. In-gel digestion of proteins for internal sequence analysis after one- or two-dimensional gel electrophoresis. Anal. Biochem. 203 : 173-179.

Song, Y. C., S. J. Lim, J. S. Lee, H. Y. Kim, U. S. Yeo, N. B. Park, D. Y. Kwak, J. R. Kang, S. J. Yang, H. G. Hwang, B. G. Oh, H. P. Moon, and M. S. Lim. 2008. A new high amylose rice variety "Goamibyeo". Kor. J. Breed Sci. 40 : 447-451.

Vorm, O., P. Roepstorff, and M. Mann. 1994. Improved resolution and very high sensitivity in MALDI-TOF of matrix surfaces made by fast evaporation. Anal. Chem. 66 : 3281-3287. 